Ks. Stanisław Dyk

Verbum Vitae 28 (2015) 401-422

\title{
MIEJSCE ŚWIADECTWA W PRZEPOWIADANIU HOMILIJNYM
}

\section{The Place of Testimony when Preaching a Homily}

Abstract: The homily is a natural place to give Christian witness. God's self-revelation - the continuation of which is found in the preaching of God's Word - is characterized by dialogue. God, in giving Himself through the preaching of the Word, witnesses about Himself and waits for man's reply, which is born from man's personal experience of meeting God. This response then takes on the character of man's own witness about meeting God. The witness of a Christian's life is the confirmation of the power of God's Word, it's verification and illustration. When preaching a homily, witnessing to the faith can be voiced in different ways, but is always to be proclaimed by the homilist. The preacher of God's Word can indirectly deliver experiencing God through one of the believers, or in his own words. The homilist is to witness that he "saw and heard" (experienced) God - in the Word of God, in the liturgy, and the lives of believers. Thus, the homily is listening to Christ who is present in Sacred Scripture, perceiving Him in the framework of the liturgy, and giving witness about His work in the life of the believer.

Keywords: the homily, witness, testimony, Christ's presence, the Word of God, the liturgy, the life of believers, salvation history

Streszczenie: Homilia jest naturalnym miejscem chrześcijańskiego świadectwa. Objawienie Boże, którego kontynuacją jest 
przepowiadanie słowa Bożego, ma bowiem charakter dialogiczny. Bóg, udzielając siebie samego w głoszeniu Słowa, daje świadectwo o sobie oraz oczekuje na odpowiedź człowieka, która rodzi się z doświadczenia osobowego spotkania z Nim. Odpowiedź ta przyjmuje zatem charakter świadectwa o spotkaniu człowieka z Bogiem. Świadectwo chrześcijańskiego życia jest potwierdzeniem mocy słowa Bożego, jego weryfikacją i ilustracją. W przepowiadaniu homilijnym świadectwo wiary może dojść do głosu w różny sposób, zawsze jednak z ust homilisty. Głosiciel słowa Bożego może w sposób pośredni przekazać doświadczenie Boga kogoś z wierzących lub swoje własne. Homilista ma zaświadczyć o tym, że ,,widział i słyszał” (doświadczył) Boga w słowie Boże, w liturgii i w życiu wiernych. Homilia jest bowiem słuchaniem Chrystusa obecnego w Piśmie Świętym, oglądaniem Go w ramach liturgii oraz zaświadczaniem o Jego działaniu w życiu wierzących.

Słowa klucze: homilia, świadectwo, obecność Chrystusa, słowo Boże, liturgia, życie wierzących, historia zbawienia

Homilia w sposób naturalny jest miejscem, w którym powinno wybrzmieć świadectwo chrześcijańskiego życia. Objawienie Boże, którego kontynuacją jest przepowiadanie słowa Bożego, ma bowiem charakter dialogiczny. Bóg, udzielając siebie samego w głoszeniu słowa (por. KO 2), daje świadectwo o sobie oraz oczekuje na odpowiedź człowieka, która rodzi się z doświadczenia osobowego spotkania z Nim. Odpowiedź ta przyjmuje zatem charakter świadectwa o spotkaniu człowieka z Bogiem. Świadectwo chrześcijańskiego życia jest potwierdzeniem mocy słowa Bożego, jego weryfikacją i ilustracją. W przepowiadaniu homilijnym świadectwo dochodzi do głosu zawsze poprzez usta homilisty, dla którego zastrzeżone jest głoszenie słowa Bożego w ramach liturgii ${ }^{1}$. Głosiciel słowa Bożego

${ }^{1}$ Obecne przepisy liturgiczne zabraniają, aby świadectwo w czasie homilii składała osoba niewyświęcona. Wyjątek stanowią tutaj liturgie dla wspólnot Neokatechumenalnych oraz Msze Święte z udziałem dzieci. Por. np. Kongregacja Kultu Bożego i Dyscypliny Sakramentów, Dyrektorium Homiletyczne, 5. 
może w sposób pośredni przekazać doświadczenie Boga kogoś z wierzących lub bezpośrednio swoje własne.

Świadectwo homilisty opiera się na podstawowym paradygmacie - na Jezusie Chrystusie, który przychodzi do ludzi jako świadek Ojca - zaświadcza o tym, co widział i słyszał u Ojca (J 3,32; por. J 1,18; 3,11; 8,38; $14,6-11 ; \mathrm{J} 18,17)$. On jest też pierwszym wykonawcą słowa, które głosi (por. J 10,25). Słowa Jezusa były pełne mocy również dlatego, że Jego życie było zgodne z Jego słowami - Jezus jest, ,świadkiem wiernym” objawienia przyniesionego od Ojca (por. Ap 1,5; 3,14). W paradygmat Jezusowego świadectwa wpisują się także apostołowie, którzy swoje głoszenie Ewangelii motywują słowami: „Bo my nie możemy nie mówić tego, cośmy widzieli i słyszeli" (Dz 4,20; 26,16; por. J 1,1-3). To doświadczenie Boga w Jezusie Chrystusie odnosi się zarówno do spotkania $\mathrm{z}$ historycznym wydarzeniem Jezusa Chrystusa (por. J 1,32.39; 5,19; 19,35; 1J 1,1-4), jak też do osobistej (często mistycznej) relacji z wcielonym Synem Boga dostępnej poprzez wiarę (por. np. $1 \mathrm{~J} 5,10)^{2}$. Doświadczenie to staje się koniecznym kryterium zaliczenia w poczet apostołów (por. Dz 1,21-22). Stąd też posłannictwo apostołów określane jest często w Nowym Testamencie terminem ,'świadectwo" (por. Łk 24,45-49; J 15,27; Dz 1,8; 2,32; 3,15; $10,39 ; 22,15)^{3}$.

W perspektywę świadectwa Jezusa i apostołów wpisują się wszyscy kapłani, jako współpracownicy biskupów - następców apostołów. Związek pomiędzy głoszeniem słowa Bożego a świadectwem potwierdza także Sobór Watykański II (por. KK 21; KO 18; DM 11; DK 11; DWR 11; KDK 43), jak też późniejsze nauczanie papieży dotyczące ewangelizacji ${ }^{4}$. Kluczem do właściwego wykonywania posługi słowa Bożego przez homilistę jest zatem doświadczenie Boga w osobistej relacji z Nim oraz potwierdzanie tego doświadczenia swoim życiem. Homilista ma stanąć

\footnotetext{
${ }^{2}$ Por. Siwek, „Kaznodzieja”, 89-92.

${ }^{3}$ Por. Jankowski, Kerygmat, 118; Pagiewski, Głoszenie, 78.

${ }^{4}$ Zob. EN 22,42; ChL 34; RM 42-44; PDV 22,26; VS 107.
} 
przed uczestnikami zgromadzenia liturgicznego jako ten, który widział i słyszał zbawiającego Pana w proklamowanym słowie Bożym, w liturgii oraz w życiu wierzących (także i w swoim własnym). Homilia jest przekazem doświadczenia, które stało się najpierw udziałem samego homilisty, zgodnie z zasadą opisaną przez św. Pawła: „Cóż masz, czego byś nie otrzymał" (1 Kor 4,7).

\section{Homilia świadectwem spotkania Chrystusa OBECNEGO W SLOWIE BOŻYM}

Według Orygenesa - jednego z „ojców” chrześcijańskiej homilii - przepowiadanie homilijne jest wydarzeniem zbawczym polegającym na doprowadzeniu uczestników liturgii do spotkania z Chrystusem obecnym w Piśmie Świętym $^{5}$. Na bazie rozumienia tekstu biblijnego jako wcielenia się Logos w słowo Pisma Świętego Orygenes pojmuje homilię jako poszukiwanie Chrystusa w tekście świętym w obecności słuchaczy. Takie przepowiadanie prowadzi też, jego zdaniem, do poznania i umiłowania Chrystusa ${ }^{6}$.

Wedle takiego rozumienia homilii głoszący słowo Boże powinien stanąć przed zgromadzeniem liturgicznym jako ten, który już spotkał Chrystusa obecnego w tekście świętym. Ma jawić się jako ten, który spotkał tam Pana i uwierzył $\mathrm{Mu}^{7}$. Dlatego może on powiedzieć za św. Pawłem: „uwierzyłem, dlatego przemówiłem” (2 Kor 4,13). Wówczas, jak pisze Leszek Kuc, będzie on „mógł przemawiać do braci już nie tylko we własnym imieniu"s. Jego

${ }^{5}$ Por. Staniek, „Kazanie”, 20. Jezus Chrystus był dla Orygenesa podstawowym kluczem w interpretacji Pisma Świętego. Do Chrystusa odnosił on każde wydarzenie, każde, nawet najmniejsze słowo zapisane na kartach Pisma Świętego. Zob. Szram, „Chrystus”, 225-238.

${ }^{6}$ Por. Olivar, La predicación, 62-69.

${ }^{7}$ Homilista powinien być pierwszym słuchaczem Chrystusa obecnego w słowie Bożym - powinien być ,pierwszym «wierzącym» w Słowo" (PDV 26).

${ }^{8}$ Kuc, „Teologia kaznodziejstwa”, 168. 
homilia staje się bowiem rodzajem osobistego wyznania wiary9.

Przepowiadanie homilijne zakłada zatem wcześniejsze obcowanie homilisty z Chrystusem obecnym w słowie Bożym, zakłada zażyłość z Nim. Homilista osiagnnie ten sposób poznania Pana, jeśli poświęci odpowiedni czas zarówno na naukowe studium tekstu biblijnego uwzględniające egzegetyczne i teologiczne zasady jego interpretacji ${ }^{10}$, jak też i na jego kaznodziejską medytację ${ }^{11}$. Szczególne znaczenie posiada w tym względzie medytacja kaznodziejska. Jest ona otwarciem się na natchnienie Ducha Świętego, który jest pierwszym ,,świadkiem” Chrystusa (por. J 15,26-27; 5,32) oraz głównym interpretatorem osoby i zbawczego dzieła Chrystusa. Tego rodzaju ,pobożna lektura" (KO 25) prowadzi do duchowego odczytania tekstu, które nazwać można pełniejszym poznaniem Pana przemawiającego w Biblii. Konieczność działania Ducha Świętego w interpretacji Pisma zakłada także fakt, że nie ma identyczności między słowem Boga a Pismem. Pismo nie jest bezpośrednio słowem Boga. Ono ,zawiera Słowo Boga" (KO 24), lecz go całkowicie nie wyczerpuje. Pismo jest jakby świadkiem Słowa, „sakramentem”, w którym to Słowo może być usłyszane. Aby Pismo mogło objawić homiliście Chrystusa, przekazywać mu Jego słowo, potrzebna jest owa duchowa hermeneutyka - działanie Ducha Świętego. Taki jest właśnie podstawowy cel kaznodziejskiej medytacji tekstu biblijnego. Cel ten trafnie oddają słowa Henryka Witczyka:

Medytacja umożliwia odkrycie Prawdy, która ma swe ostateczne źródło w Chrystusie, a nawet ma wyraźne oblicze Chrystusa - jest Prawdą-Osobą, nie ideą, abstrakcyjną tezą, definicją katechizmową, dogmatem. Odkrycie osobowego wymiaru Prawdy Pisma jest w nas możliwe

\footnotetext{
${ }^{9}$ Por. Siwek, „Kaznodzieja”, 101.

${ }^{10}$ Zob. Dyk, „Zasady interpretacji”, 99-121.

${ }^{11}$ Zob. Twardy, „Medytacja kaznodziejska”, 130-138.
} 
dzięki działaniu Ducha Prawdy, który objawia, czyli uobecnia w czytającym Chrystusa ${ }^{12}$.

Pierwsze świadectwo w homilii wyrasta zatem $\mathrm{z}$ exegesis i meditatio słowa Bożego. W ten sposób homilia wpisuje się w pneumatologiczny proces objawiania i widzenia Chrystusa: Duch Święty, który wzbudził Słowo w hagiografie, doprowadził go do spisania tego Słowa, pomaga homiliście wydobyć to samo Słowo z Pisma, a następnie ożywia homilię, uobecniając w niej Pana w Jego misteriach $^{13}$. Sama homilia staje się wówczas świadectwem o świadectwie słowa Bożego, jakim jest Pismo Święte.

Medytacja kaznodziejska jest zatem tym samym, co Orygenes utrzymywał w odniesieniu do homilii: osobistym spotkaniem z Jezusem Chrystusem na kanwie słowa biblijnego. Homilista traktuje wówczas tekst jako skierowany osobiście do niego. Takie spotkanie z Chrystusem rozpoczyna się i jest przeniknięte szczerą i ufną modlitwą. Duchowa lektura Pisma Świętego charakteryzuje się kreatywnością polegającą na dostrzeżeniu szczegółów i zjawisk, które nie zostały wyrażone słowami. W ten sposób

${ }^{12}$ Witczyk, Rola biblistyki, 151. Por. Bonhoeffer, La parola predicata, 46-48.

${ }^{13}$ Por. Simon, „Przepowiadanie biblijne”, 79-81. Francuski teolog Jean-Jacques von Allmen, wskazując na uroczystą wymowę wydarzenia, jakim jest lektura i przepowiadanie słowa Bożego w czasie kultu, podkreśla między innymi: „Kiedy wykonuje się lekturę Biblii następuje pewna fundamentalna rzecz: świadek, którego świadectwo zostało «pogrzebane» w lekturze, podnosi się, aby podjąć to Słowo. To wydarzenie możliwe jest dzięki działaniu Ducha Świętego. Lektura Pisma musi zostać poprzedzona epiklezą, ponieważ to dzięki Duchowi Świętemu zachodzi to swoiste zmartwychwstanie Pisma i jego wejście w Słowo, a Pismo pod formą lektury znajduje swoje usprawiedliwienie i swoje miejsce w kulcie Kościoła: lektura rzeczywiście zostaje wykonana po to, aby świadek powrócił do świadczenia a anagdosi stało się anamneza, to znaczy aby to, co zostało powiedziane $\mathrm{w}$ innym czasie i na innym miejscu, zostało wypowiedziane na nowo w sposób żywy i nowy, tu i teraz”. Tenże, Celebrare la salvezza, 11. 
prowadzi do odczytania całej głębi tekstu, dostrzeżenia jego wewnętrznego bogactwa ${ }^{14}$.

Gdy homilia będzie wypływać z głębokiej duchowości, modlitwy i medytacji słowa Bożego, wówczas istnieje prawdopodobieństwo, że jego słuchacze przeżyją je z równą intensywnością ${ }^{15}$. Homilia, która zrodzi się z medytacji Chrystusa w słowie Bożym, w sposób naturalny zmierza potem także do kontemplacji Jego Osoby obecnej i działającej w „tu i teraz” liturgii. Swiadectwo o Chrystusie obecnym w słowie Bożym dochodzi do głosu w sposób autentyczny jedynie w homilii pogłębionej na wzór: $m e$ ditatio - contemplatio.

Chrystusa i Jego zbawczych misteriów nie da się bowiem zrozumieć i głosić w sposób czysto intelektualny, lecz domagają się one pokory i pełniejszego wniknięcia w nie przez wiarę ${ }^{16}$, tak jak to stwierdza Romano Guardini: „Należy raczej zatrzymać się w obliczu danego wydarzenia, danych słów, danego czynu, nasłuchując, ucząc się, adorując i okazując posłuszeństwo" "17. Przepowiadanie homilijne ma zatem oscylować nie w kierunku teologii ,,racjonalno-spekulatywnej”, lecz teologii „monastycznej” czy „mądrościowej”, wyrastającej swymi korzeniami z tradycji ojców Kościoła. Misteria Jezusa zgłębiali oni przede wszystkim za pomocą meditatio. Punktem wyjścia i dojścia ich teologii była wiara przeżywana, żywa i nadająca się do przeżycia. Jej uwaga była skierowana bardziej na doświadczenie niż na wyjaśnienie i zrozumienie ${ }^{18}$. W przepowiadaniu na wzór meditatio, podobnie jak w teologii i duchowości, przy rozważaniu misteriów Jezusa chodzi o określony sposób widzenia, poznania i doświadczenia, który usiłuje przeniknąć aż do głębi, aż do samego jądra poszczególnych danych i okoliczności:

${ }^{14} \mathrm{~W}$ sposób bardziej precyzyjny kaznodziejską medytację nad tekstem biblijnym opisują m.in.: Zerfass, Od perykopy do homilii, 122-126; Witczyk, Rola biblistyki, 146-152.

${ }^{15}$ Por. Twardy, „Kazanie jako akt”, 157n.

${ }^{16}$ Por. Królikowski, „Mysteria”, 90.

${ }^{17}$ Guardini, Bóg. Nasz Pan, 6.

${ }^{18}$ Por. Schütz, ,Tajemnice życia”, 16-18. 
Tutaj osoba kontemplująca dochodzi do intensywnego spotkania i kontaktu ze Słowem Wcielonym, z jądrem Jego unii hipostatycznej, z Jego byciem Synem, z Jego synowskim zachowaniem się i synowskimi uczuciami. Spojrzenie osoby kontemplującej nie jest na stałe utkwione w pojedynczej tajemnicy Jezusa, lecz się poszerza i pogłębia aż do osiągnięcia trynitarnych głębi Bożej miłości i Trójcy immanentnej ${ }^{19}$.

Homilista, który posiada takie doświadczenie (,widzenie") Pana, prowadzi wiernych do kontemplacji misteriów Chrystusa z wiarą i miłością. W ten sposób może sprawić, że jego homilia stanie się rodzajem kontemplacji, która wprowadza wiernych ,w naturalny sposób w życie Chrystusa”, pozwala im ,jakby «oddychać» Jego uczuciami”, upodobnić się do Niego i nauczyć się ,życia pokornego, ubogiego, ukrytego, cierpliwego i doskonałego"20. Medytacja kaznodziejska ukształtuje również formę homilii. Jej język stanie się wtedy bogaty, żywy, obrazowy ${ }^{21}$. Styl przepowiadania zdradzać będzie natomiast pragnienie, zapał oraz zaangażowanie homilisty w głoszeniu Chrystusa. Wówczas właśnie staje się on świadkiem Chrystusa, którego spotkał i ponownie spotyka na kanwie słowa Bożego; staje się świadkiem Prawdy - Jej radości i piękna.

\section{HoMilia ŚWIADECTWEM OGLĄDANIA Chrystusa W RaMach liturgi}

Najbardziej właściwą funkcją homilii jest mistagogia, rozumiana przede wszystkim jako doprowadzanie wiernych do bezpośredniego doświadczenia Boga w liturgii. Od czasów ojców Kościoła mistagogia polega na pogłębianiu znajomości misterium zawartego w liturgii, opartym także na jego bezpośrednim doświadczeniu ${ }^{22}$. Według Enrico Mazza mistagogia to taki rodzaj wtajemniczenia

${ }^{19}$ Schütz, „Tajemnice życia”, 19n.

${ }^{20}$ Jan Paweł II, Rosarium Virginis Mariae, 19.

${ }^{21}$ Por. Zerfass, Od perykopy do homilii, 122.

${ }^{22}$ Por. Nowakowski, „Liturgia jako miejsce wtajemniczenia”, $157 \mathrm{n}$. 
w liturgię, które ma ułatwić doświadczalne zrozumienie sprawowanych obrzędów oraz misterium zbawczego w nich ukrytego ${ }^{23}$.

Homilista zatem to ktoś, kto inspirację do głoszenia czerpie $\mathrm{z}$ doświadczalnego poznania Pana działającego w liturgii. Na bazie takiego doświadczenia prowadzi potem wiernych do zbawczego spotkania z Panem obecnym w liturgii. Taka mistagogiczna homilia bliska jest tzw. teologii misteryjnej, która się upodabnia do mistyki i jest trwaniem przy objawiającym się Bogu oraz „współprzeżywaniem" z objawiającym się Bogiem. Według Odo Casela teologia ta jest oglądem misterium Chrystusa w świetle liturgii ${ }^{24}$. Takie jest właśnie najbardziej właściwe zadanie świadectwa w ramach homilii: ma ono ułatwić spotkanie z Chrystusem, który w liturgii buduje swój Kościół ${ }^{25}$; ma wciągnąc $w$ najgłębszą i jedyną z Nim łączność, która dokonuje się właśnie w Eucharystii. W homilii ,przede wszystkim należy rozwijać głębokie zjednoczenie z Chrystusem, jedynym i koniecznym Pośrednikiem, nie w sensie abstrakcyjnym, ale w sensie realnej obecności «tu i teraz» żyjącego Pana w akcji liturgicznej”26. Dzięki takiemu świadectwu homilisty uczestnik zgromadzenia liturgicznego nie tylko rozumie, lecz także przeżywa misteria Chrystusa, czerpie z nich niezmierne dobro, jednocześnie służąc tym misteriom. Chrześcijaństwo przestaje być wówczas światopoglądem czy systemem moralnym, a staje się aktualnie trwającą historią zbawienia. W ten sposób człowiek roz-

${ }^{23}$ Por. Mazza, „La portata teologia”, 321-338. Takie rozumienie mistagogii potwierdza także Benedykt XVI: „Liturgia ma bowiem z samej swej istoty pedagogiczną zdolność wprowadzania wiernych w pojmowanie celebrowanej tajemnicy. Dlatego w najstarszej tradycji Kościoła droga formacyjna chrześcijanina - bez zaniedbywania systematycznego nauczania prawd wiary - miała zawsze charakter doświadczalny, w którym żywe i przekonywające spotkanie z Chrystusem [...] odgrywało zasadniczą rolę". Benedykt XVI, Sacramentum caritatis, nr 64.

${ }^{24}$ Por. Migut, „Teologia wierna misterium”, 266-272.

${ }^{25}$ Por. Turowski, „Kaznodzieja świadkiem”, 260n.

${ }^{26}$ Bergamini, Chrystus świętem Kościoła, 119. 
poznaje w Kościele dzieło mistyczne, dalszy ciąg życia Chrystusa ${ }^{27}$.

Swiadectwo homilisty rodzi się zatem z liturgii, umożliwiającej ciągłe uczestnictwo w misterium Chrystusa i ponawianie dialogu zbawczego, który się w niej dokonuje. $\mathrm{Z}$ tej też racji po homilii powinno się przewidzieć chwilę milczenia, aby pokazać wiernym, że Pan, który do nich mówi, jest sakramentalnie obecny w słowie homilisty, ale też poza nim (Pan mówi też poza homilią, bo jest obecny w liturgii $)^{28}$.

Homilia, która jest świadectwem oglądania Chrystusa w ramach liturgii, nabiera także cech liturgii ${ }^{29}$ : jest miejscem spotkania z Bogiem i oddawania Mu czci. Jest czynnością uświęcającą, kultyczną i faktem zbawczym ${ }^{30}$. Homilia - świadectwo zbawczej obecności Pana, wpisuje się w naturę liturgii, i tak jak liturgia posiada wymiar zstępujący (głoszone i aktualizowane słowo uświęca wierzących; uzmysławia wierzącym uświęcający, chrystyfikujący, przebóstwiający charakter liturgii; zachęca do świętości życia) i wstępujący (uświadamiając wiernym zbawczą obecność Boga, homilia wzywa ich do dziękczynienia i oddawania chwały Ojcu, Synowi i Duchowi Świętemu) ${ }^{31}$. Homilia - świadectwo ma zatem jawić się wiernym jako liturgia oraz wprowadzać w klimat liturgii. Temu celowi służy chociażby wykorzystanie modlitwy w homilii. Powinna to być głośna modlitwa zwrócona do Chrystusa na początku lub lepiej na zakończenie homilii. Uświadomi ona słuchaczom nadprzyrodzony wymiar liturgii (obecność żyjącego Boga, który ofiaruje im komu-

${ }^{27}$ Por. Świerzawski, Mysterium Christi, 240.

${ }^{28}$ Dyk, „Homilia w Eucharystii”, 247; por. Siwek, „Ewangelizacyjna funkcja”, 88 .

${ }^{29}$ Nie należy nigdy zapominać, że homilia jest integralną częścią liturgii i w ten sposób jest także aktem liturgicznym. Por. KL 35,2; 52.

${ }^{30}$ Por. Szewczyk, Recepcja, 58n.; Przyczyna, „Przepowiadanie w liturgii", 184.

${ }^{31}$ Por. Migut, Teologia liturgiczna, 326-329. 
nię ze sobą) i wprowadzi ich w głębię danego misterium zbawczego $^{32}$.

Homilia, która jest oglądaniem Chrystusa w ramach liturgii, staje się swoistym świadectwem wiary homilisty, jego pobożności - obecności przed Bogiem. Według Andrzeja Żądło ta obecność przed Bogiem w czasie sprawowania Eucharystii jest „duszą" modlitwy, gestów i postaw, ona to właśnie gwarantuje świadome, czynne i owocne uczestnictwo:

Uczestnictwo w liturgii ma się przeradzać w akt wiary, która otwiera chrześcijanina [najpierw celebransa-homilistę, a za nim wszystkich uczestników liturgii - S.D] na niewidzialne działanie Chrystusa i Ducha Swiętego. Wszystkie więc formy Jego obecności w Kościele i w liturgii zmierzać mają do Jego duchowej obecności w sercach chrześcijan i we wspólnocie wierzących, bo celem obecności Chrystusa w liturgii jest to, aby On żył w nas i abyśmy żyli w Nim oraz dla Niego - tak jak On żył w zjednoczeniu ze swoim Ojcem i dla Ojca ${ }^{33}$.

\section{HoMilia ŚWIAdECTWEM ZBAWCZEgo dZIALANIA BOGA W ŻYCIU WIERZĄCYCH}

Homilia, jako przedłużenie słowa Bożego, przejmuje jego istotę i ma być, podobnie jak ono, świadectwem o zbawczym działaniu Boga ${ }^{34}$. Homilia jest zwiastowaniem ,,przedziwnych dzieł Bożych dokonanych w dziejach zbawienia" (KL 35), czyli w misterium Chrystusa (czego świadectwem jest Pismo Święte) i aktualizujących się dziś w Kościele (w liturgii i życiu wierzących). Treścią homilii-świadectwa jest ,,prawda o zbawieniu dokonanym w pełni czasu przez Jezusa Chrystusa (to, co Bóg uczynił) i uobecniającym mocą Ducha Świętego w Kościele (to,

${ }^{32}$ Oczywiście modlitwa taka powinna łączyć się z treścią homilii, być niejako jej modlitewnym streszczeniem.

33 Żądło, „Egzystencjalno-pedagogiczny wymiar”, 130.

${ }^{34}$ Zob. Dyk, „Homilia świadectwem”, 147-160. 
co Bóg czyni) dla ludzi wszystkich miejsc i czasów"35. Stąd też przepowiadanie homilijne powinno polegać na uobecnianiu zbawczego działania Boga. Ważnym zadaniem homilisty jest zatem zaświadczanie o Bogu, który „działa w [...] życiu [wierzących - S.D.] z taką samą dynamiką i w takim samym celu, jak to przed chwilą słyszeli w czytaniach mszalnych"36. Ten aktualizacyjny wymiar homilii przyczynia się do kształtowania historiozbawczego spojrzenia na życie chrześcijanina. Egzystencja każdego z chrześcijan na ziemi to bowiem ,ustanowiona Bożym zrządzeniem «czasowa przestrzeń» [kairos], nadająca się do tego, by w jej obrębie spełniały się i urzeczywistniały zbawcze plany wobec ludzkich istnień, a więc «przestrzeń» wybrana i podarowana ludziom przez Boga, który sam ocenia i ustanawia dogodny dla swych zamiarów czas i godzinę ich realizacji" ${ }^{\prime 3}$.

Homilia ukazuje zatem aktualny ,stan życia w świecie jako arenę, na której obecny jest i działa sam Bóg, niosąc pokrzepienie oraz stawiając wyzwania"38. Takie przepowiadanie sprawia, że wierni patrzą na własne życie jako na mocny moment historii zbawienia. Włączają swój indywidualny los w zbawczą historię. Dzięki temu potrafią powiązać ze sobą i zrozumieć wydarzenia swojego życia. Przeszłość jest dla nich owocna, bo jest $\mathrm{z}$ wdzięcznością wspominana tak, jak Eucharystia jest uobecnieniem zbawczych, minionych już dzieł Boga. To uobecnianie zbawczej przeszłości sprawia, że człowiek żyjący liturgią myśli w sposób historyczny, jest człowiekiem posiadającym ojczyznę, posiadającym korzenie. Nie jest ofiarą przelotnego momentu, chwili. Widzi powiązania. Wierzy w sens historii. Poprzez wierzącego zjednoczonego z Chrystusem przeszłość przynosi owoce dla teraźniejszości i przyszłości - poprzez wspomnienie zbawczych dzieł Boga prze-

${ }^{35}$ Brzuszek, „Kerygmat w teologii dogmatycznej”, 1363-1364.

${ }^{36}$ Por. Franciszek, Evangelii gaudium, 147.

${ }^{37}$ Żądło, „Egzystencjalno-pedagogiczny wymiar”, 132.

${ }^{38}$ Komisja do spraw Życia i Posługi Kapłanów przy Krajowej Konferencji Biskupów Katolickich USA, Dziś spetnity się stowa Pisma, 32. 
szłość staje się oparciem, umocnieniem, wewnętrzną siłą, która każe z nadzieją patrzeć w przyszłośćc ${ }^{39}$. Stąd też Josef A. Jungmann podkreślał, że kerygmat jest „Radosną Nowiną" wnoszącą światło w codzienność. W ten sposób staje się on autentyczną siłą kształtującą codzienność ${ }^{40}$. Homilia - świadectwo o zbawczym działaniu Boga w życiu wierzących - buduje ich wiarę - ,towarzyszkę życia, która pozwala nam dostrzegać nieustannie na nowo cuda, jakich Bóg dla nas dokonuje" ${ }^{41}$; która przekonuje o prawdziwości słów Jezusa: „Ojciec mój działa aż do tej chwili i Ja działam" (J 5,17).

Homilijne świadectwo o tym, że życie współczesnego człowieka jest historią zbawienia, jest szczególnie aktualne w kontekście współczesnych uwarunkowań kulturowych. Wydaje się bowiem, że w dzisiejszej kulturze nie ma miejsca dla opatrznościowego, transcendentnego planu, który nadawałby sens, treść, kierunek ludzkiej egzystencji. Współczesny człowiek skupia się na samym sobie, bez odnoszenia się do idei pozaziemskich, bez upatrywania sensu i kierunku historii. Świat rozumiany jest jako ten, który posuwa się na przód sam przez się, chaotycznie, w sposób pozbawiony sensu ${ }^{42}$. Takie pojmowanie świata wpływa bez wątpienia na sposób myślenia i postępowania wielu wierzących. Papież Franciszek w swojej encyklice o wierze Lumen fidei tak komentuje ten sposób patrzenia na ludzkie życie:

Nasza kultura straciła zdolność dostrzegania konkretnej obecności Boga, Jego działania w świecie. Uważamy, że Bóg znajduje się w zaświatach, na innym poziomie rzeczywistości, oddzielony od naszych konkretnych relacji. Gdyby jednak tak było, gdyby Bóg nie był zdolnym do działania w świecie, Jego miłość nie byłaby prawdziwie potężna, prawdziwie rzeczywista, a zatem nie byłaby nawet prawdziwą miłością, zdolną zapewnić to szczęście,

${ }^{39}$ Por. Häring (Sartore), „Esistenza cristiana e liturgia”, 708.

${ }^{40}$ Por. Lewek, Funkcja kerygmatyczna, II, 68-69.

41 Benedykt XVI, Porta fidei, 15.

42 Por. Pistoia, „Storia di salvezza”, 1513. 
które obiecuje. Wówczas byłoby całkowicie obojętne, czy się w Niego wierzy, czy nie wierzy ${ }^{43}$.

Konsekwencją takiego rozumienia własnego życia jest także nieumiejętność właściwego przeżywania liturgii. Chodzi tu o nieumiejętność postrzegania liturgii jej jako mocnego momentu historii zbawienia. Celebracja liturgiczna przeżywana jest jako abstrakcyjny moment historii, zamknięty w sobie samym, niezdolny do tego, by wzbudzić u wiernych świadomość wpisywania się w Boży plan zbawienia, a tym samym świadomość wezwania, na które trzeba odpowiedzieć, misji i współpracy, które trzeba podjąć. Jednym słowem - moment celebracji liturgicznej nie osiąga poziomu doświadczenia wiary żywej i aktywnej. Liturgia nie sprawia, że wierni żyją tym planem zbawienia i że staje się on dla nich przedmiotem nadziei, z którego wypływa sens życia $\mathrm{i}$ ich własne przekonania ${ }^{44}$.

Przepowiadanie homilijne, jako świadectwo o zbawczym działaniu Boga, winno zatem rodzić wiarę pomagająca postrzegać swe życie jako arenę, na której działa Bóg. Taką wiarę papież Franciszek nazwie ,światłem na drodze, wskazującym kierunek naszej wędrówki w czasie"45. Do kształtowania takiej wiary potrzebny jest homilista - prorok, który ma „oczy wiary” pomagające mu dostrzec Pana zbawczo działającego w codziennym życiu ludzi (w tym i w jego własnym życiu); dostrzec „,konkretną i potężną miłość Boga, który naprawdę działa w historii i decyduje o jej ostatecznym przeznaczeniu"46. Powinien on odczytywać „dzisiaj” jako miejsce, w którym możliwa jest inkarnacja wydarzenia, które dokonało się w historii. Wymaga się tu od homilisty, aby był człowiekiem żywej wiary i świadkiem, który własne życie poddał przemieniającemu działaniu Ewangelii oraz dostrzega to działanie w Kościele.

\footnotetext{
${ }^{43}$ Franciszek, Lumen fidei, 17.

44 Por. Pistoia, ,Storia di salvezza”, 1513.

45 Franciszek, Lumen fidei, 4.

${ }^{46}$ Franciszek, Lumen fidei, 17.
} 
Zbawcze działanie Boga homilista powinien zobaczyć w życiu wspólnoty, którą reprezentuje przed Panem (wówczas też składa świadectwo widzenia Pana), a także we własnym życiu ${ }^{47}$. W przepowiadaniu homilijnym mogą pojawić się zatem osobiste wątki doświadczenia życiowego i wiary samego homilisty. Jest on przecież konkretnym wierzącym - podmiotem zbawczego dialogu z Bogiem. Może mówić o tym, czego doświadczył - o doświadczonym zbawieniu ${ }^{48}$. Jest to $\mathrm{w}$ jakimś sensie wypowiadanie siebie, osobiste wyznanie. Homilista powinien być jednak świadom, że to nie jego wyznanie i nie jego osoba są ważne. Ważny jest przedmiot jego doświadczenia: osoba Jezusa Chrystusa poznana przez wiarę. To właśnie zachęta do spotkania i doświadczenia osobowego Boga jest przecież celem zamieszczenia w homilii wątku osobistego świadczenia ${ }^{49}$. Homilista powinien pamiętać także, jak to stwierdza najnowsze Dyrektorium Homiletyczne, że homilia ma być przede wszystkim głoszeniem Chrystusa i wiary Kościoła, a nie jego osobistej historii ${ }^{50}$. To znaczy, że osobiste świadectwo homilisty nie powinno być nigdy tematem homilii. Ma ono wybrzmieć jakby „przy okazji” głoszonego słowa Bożego i celebrowanego zbawczego misterium. Osobiste świadectwo homilisty nie może mieć również zbyt intymnego charakteru - być czymś w rodzaju „duchowego striptizu”. Wówczas bowiem może zakłócić

${ }^{47}$ Zob. Müller, Homiletyka, 227-229.

${ }^{48}$ Por. Przyczyna, „Funkcje kaznodziei”, 202.

${ }^{49}$ Element osobistego świadectwa homilisty nie tylko ilustruje zbawcze orędzie, lecz jest jednocześnie jego potwierdzeniem i umocnieniem. Osobiste świadectwo homilisty zwiększa skuteczność przepowiadania także ze względu na psychologiczne uwarunkowania odbioru homilii. Otóż słuchacz słowa Bożego nie jest w stanie uwierzyć w głoszoną treść samą w sobie, abstrahując całkowicie od jej głosiciela. Im bardziej głoszący jest świadkiem Słowa tym większy wpływ wywiera na słuchaczy. Por. Biela, „Uwarunkowania psychologiczne”, 106.

${ }^{50}$ Por. Kongregacja Kultu Bożego i Dyscypliny Sakramentów, $D y$ rektorium homiletyczne, $\mathrm{nr}$ 6-7. 
sacrum Bożego słowa i liturgii oraz wprowadzać słuchaczy w zakłopotanie ${ }^{51}$.

Homilista powinien nosić w sobie żywe odczucie zbawczej obecności Boga. Doświadczenie to powinno inspirować do przepowiadania i przenikać słowa homilii. „Świadek musi zatem najpierw być, zanim coś uczyni. Musi być przyjacielem Jezusa Chrystusa, aby nie przekazywał tylko przekonania z drugiej ręki, lecz rzeczywiście był świadkiem" 52 . Wówczas także homilista komunikuje Chrystusa - pomaga w nawiązaniu osobistej relacji między słuchaczami swej homilii a Chrystusem obecnym w liturgii eucharystycznej. W innym przypadku homilia może się jawić wiernym jedynie jako bezosobowa relacja kogoś, kto wyznacza z urzędu wymagania, które chrześcijanin ma przyjąć i realizować w życiu ${ }^{53}$.

Osobiste świadectwo homilisty złożone podczas przepowiadania należy pojmować podwójnie: jako „widzenie” Boga w codziennym życiu (o czym była mowa powyżej) oraz jako wierność Bożym słowom w codziennym życiu (słowo przeżywane, świętość życia) ${ }^{54}$. Nie należy zapominać, że przepowiadanie homilijne nie jest głoszeniem jakiejś doktryny, którą przekazał nam Jezus. Tym samym nie jest także prostym nauczaniem innych. Jest natomiast świadectwem tego, czego my sami nauczyliśmy się od Chrystusa. W taki sposób swoją posługę ewangelisty określał św. Paweł: „Bądźcie naśladowcami moimi, tak jak ja jestem naśladowcą Chrystusa” (1 Kor 11,1): „A wy, przyjmując słowo, pośród wielkiego ucisku, z radością Ducha Świętego, staliście się naśladowcami naszymi i Pana" (1 Tes 1,6). Homilista musi być najpierw sam ukształtowany przez słowo zbawienia; musi stać się tym, co usłyszał; ma stać się żywą Ewangelią, opowieścią, która przypo-

${ }^{51}$ Por. Müller, Homiletyka, 228; Sorentino, Celebracje liturgiczne, 135.

${ }^{52}$ Ratzinger, „Posługa świadka”, 470. Por. tamże, 469.

${ }^{53}$ Por. Siwek, „Kaznodzieja”, 102.

${ }^{54}$ Por. Siwek, „Kaznodzieja”, 96-99. Zob. PDV 25; RM 90; VS 107. 
mina i powtarza to, co uczynił i przeżył Jezus ${ }^{55}$. Słowo homilisty staje się wiarygodne, jeśli on sam jest widzialnym znakiem tego, co to słowo oznacza - tego, jaki dar nowego życia w Chrystusie objawia. Prawdę tę podkreśla Benedykt XVI: „Ważne jest [...], by w każdej formie przepowiadania pamiętano przede wszystkim o wewnętrznym związku między przekazywaniem Słowa i świadectwem chrześcijańskim. Od tego uzależniona jest sama wiarygodność tego, co się głosi" "56. Nie chodzi tu jedynie o dobry przykład, lecz o doświadczenie Boga poprzez wiarę, o osobistą zażyłość ze zmartwychwstałym Chrystusem o przeżywanie w sobie Jezusowej egzystencji, o współodczuwanie z Nim:

Głoszone orędzie ma wzywać do przemiany życia. Przekonująco może je przekazywać ktoś, kto sam podobną przemianę przeżył, zakosztował zbawiennych jej owoców, a więc $z$ własnego doświadczenia mówi o sensowności podobnej przemiany i szczerze wzywa innych do jej dokonania ${ }^{57}$.

Słowa przepowiadania, które nie odnoszą się do Jezusa obecnego w doświadczeniach naszego życia, są w zasadzie mówieniem o niczym. Słowa takie nie mają dużej wagi, jeśli nie zostają potwierdzone przez doświadczenie żywego Jezusa. Głoszenie Ewangelii musi być zgodne z tym, jak się żyje. Jeśli postępuje się inaczej, to nawet jeśli mówi się prawdę, to czyni się to tylko po to, by oszukać. Istnieje niebezpieczeństwo, że homilista stanie się wówczas jedynie doktrynerem, moralizatorem bądź nawet podobnym do zawodowych kłamców, którzy potrafią mówić z przekonaniem, jak gdyby wierzyli w to, co mówią; lecz mówią tak tylko dlatego, aby inni w to uwierzyli. Słowa przydają się, jeśli odpowiadają faktom; w przeciwnym razie są jedynie pułapkami. W ten sposób dyskredytuje się prawdę Ewangelii ${ }^{58}$.

${ }^{55}$ Fausti, Jak rozważać i głosić, 144.

56 Benedykt XVI, Verbum Domini, 97.

57 Siwek, „Kaznodzieja”, 97. Por. Pagiewski, Głoszenie, 31.

58 Por. Fausti, Jak rozważać i głosić, 135, 146. 


\section{Podsumowanie}

Świadectwo chrześcijańskiej wiary ma swoje naturalne miejsce w przestrzeni przepowiadania homilijnego. Spełnia ono jednak funkcję służebną wobec podstawowej treści homilii, jaką jest kerygmat tekstów świętych i sprawowane misterium. Homilista jest świadkiem wiary wówczas, jeśli osobiście spotka Pana obecnego w słowie Bożym, zbawczo działającego w liturgii, w jego własnym życiu, a także w otaczającym go świecie i wydarzeniach codzienności. Własne świadectwo wiary homilista winien konfrontować $\mathrm{z}$ orędziem tekstów świętych oraz nauką Kościoła, przez który jest posłany. Tym samym będzie on mógł poprzeć swoje świadectwo autorytetem Boga, Chrystusa, Kościoła, w imieniu którego przemawia ${ }^{59}$.

Osobiste świadectwo homilisty wpływa także na sposób wykonywania posługi przepowiadania. Świadectwo (czy antyświadectwo) przynależy do aktu komunikacji, gdyż każdy nadawca wypowiada siebie nawet wówczas, kiedy bardzo pragnie siebie ukryć - słowo jest objawieniem osoby, objawieniem osobistego stosunku do przekazywanej treści ${ }^{60}$. Widzialną cechą świadka pozostaje zaangażowanie i pasja wyrażająca się w pragnieniu opowiadania, proklamacji ${ }^{61}$ : „Świadek nie mówi dla efektu jak oszust, lecz skromnie wyraża to, co przeżywa jako wartość; i przekazuje to innym, aby mogli się tym razem z nim cieszyć (por. $1 \mathrm{~J}$ 1,1-4)"'62.

Do smutnych wniosków prowadzić może zatem obserwacja narastającej praktyki odczytywania przez homilistów w czasie liturgii tekstów cudzych homilii. Może to

${ }^{59}$ Por. Siwek, „Kaznodzieja”, 95.

${ }^{60}$ Por. Siwek, „Kaznodzieja”, 98. Kazania mówią nie tylko o Bogu (bardziej w treści), ale i o kaznodziei (bardziej przez formę). Sikora, Od Stowa do stowa, 69.

${ }^{61}$ Sławiński, „Homilia w niedzielnym zgromadzeniu”, 43n.

${ }^{62}$ Fausti, Jak rozważać i głosić, 136. „Jeśli adorujemy Chrystusa w naszych sercach, to zawsze jesteśmy gotowi odpowiedzieć każdemu, kto pyta nas o powody nadziei, jakie w nas widzi. I czynimy to łagodnie, z szacunkiem i czystym sumieniem (1 P 3,15nn.)”. Tamże, 144. 
być niezamierzony zabieg ukrycia przez homilistę własnego stosunku do proklamowanego orędzia. Homilista nie chce świadczyć (bo może tego doświadczenia nie ma), więc ukrywa się za obcym świadectwem Słowa. Jednak i taki zabieg ujawnia homilistę - komunikuje słuchaczom swój brak świadectwa lub wręcz antyświadectwo. Jeśli bowiem forma kłóci się z treścią, to treść zostaje zdementowana przez formę.

\section{Bibliografia}

Benedykt XVI, Adhortacja Sacramentum Caritatis (2007).

Benedykt XVI, Adhortacja Verbum Domini (2010).

Benedykt XVI, List Porta fidei (2011).

Bergamini A., Chrystus świętem Kościoła. Rok liturgiczny.

Historia, celebracja, teologia, duchowość, duszpasterstwo (Kraków 2003).

Biela B., „Uwarunkowania psychologiczne i społeczne przepowiadania”, Studia Pastoralne 7 (2011) 100-118.

Bonhoeffer D., La parola predicata. Corso di omiletica a Finkenwalde (1935-1939) (Torino 1995).

Brzuszek B., „Kerygmat w teologii dogmatycznej”, Encyklopedia katolicka (red. Antoni Bednarek et al.) (Lublin 2000) VIII, 1363-1364.

Dyk S., „Homilia świadectwem o zbawczym działaniu Boga”, Studia Leopoliensa 7 (2014) 147-160.

Dyk S., „Homilia w Eucharystii niedzielnej”, Roczniki Teologiczne 53/8 (2006) 241-251.

Dyk S., „Zasady interpretacji tekstu biblijnego w praktyce kaznodziejskiej”, Perspectiva. Legnickie Studia Teologiczno-Historyczne 8 (2009), nr 1 (14) 99-121.

Fausti S., Jak rozważać i glosić Pismo Święte (Kraków 2010).

Franciszek, Adhortacja Evangelii Gaudium (2013).

Franciszek, Encyklika Lumen fidei (2013).

Guardini R., Bóg. Nasz Pan Jezus Chrystus. Osoba i życie (Warszawa 1999). 
Häring B. (D. Sartore), „Esistenza cristiana e liturgia”, Liturgia (red. D. Sartore - A.M. Triacca - C. Cibien) (Milano 2001) 705-711.

Jan Paweł II, Adhortacja Christifideles laici (1988) (= ChL). Jan Paweł II, Adhortacja Pastores Dabo Vobis (1992) (= PDV). Jan Paweł II, Encyklika Redemptoris Missio (1990) (= RM). Jan Paweł II, Encyklika Veritatis splendor (1993) (=VS). Jan Paweł II, List apostolski Rosarium Virginis Mariae (2002). Jankowski A., Kerygmat w Kościele apostolskim (Częstochowa 1989).

Komisja do spraw Życia i Posługi Kapłanów przy Krajowej Konferencji Biskupów Katolickich USA, „Dziś spetnity sie stowa Pisma...". Homilia $w$ niedzielnym zgromadzeniu wiernych (Włocławek 2002).

Kongregacja Kultu Bożego i Dyscypliny Sakramentów, Dyrektorium Homiletyczne (Città del Vaticano 2014).

Królikowski J., „Mysteria «vitae Christi» a poszukiwania współczesnej chrystologii”, J. Ratzinger - J. Królikowski, Z Chrystusem $w$ historii. Rozważania chrystologiczne (Kraków 1999) 79-92.

Kuc L., „Teologia kaznodziejstwa po Soborze Watykańskim II”, Studia z historii kaznodziejstwa i homiletyki (red. L. Kuc W. Wojdecki) (Warszawa 1975) I, 165-178.

Lewek A., Funkcja kerygmatyczna Kościoła w świetle Vaticanum II. Istota i zadania (Warszawa 1984).

Mazza E., „La portata teologia del termine mistero”, Rivista Liturgica 74 (1987) 321-338.

Migut B., „Teologia wierna misterium według Odona Casela OSB (1886-1948)", Roczniki Teologiczne 52/8 (2005) 261275.

Migut B., Teologia liturgiczna szkoły rzymskiej (Lublin 2007). Müller K, Homiletyka na trudne czasy (Kraków 2003).

Nowakowski P., ,Liturgia jako miejsce wtajemniczenia i doświadczenia nowości wiary - środkiem czy celem ewangelizacji”, Nowy człowiek $w$ dziele nowej ewangelizacji (red. G.W. Dryl) (Kraków 2013) 153-168.

Olivar A., La predicación cristiana antigua (Barcelona 1991). Pagiewski H., Głoszenie słowa Bożego jako świadectwo (Warszawa 1971). 
Paweł VI, Adhortacja Evangelii nuntiandi (1975) (= EN).

Pistoia A., „Storia di salvezza”, Dizionario di Omiletica (red.

M. Sodi - A.M. Triacca) (Torino - Bergamo 1998) 15131519.

Przyczyna W., „Funkcje kaznodziei i ich odzwierciedlenie językowe", Stuga Stowa (red. W. Przyczyna) (Redemptoris Missio 13; Kraków 1997) 202-206.

Przyczyna W., „Przepowiadanie w liturgii. Cechy posoborowej homilii”, Ateneum Kapłańskie 126 (1996) 179-187.

Ratzinger J., „Posługa świadka. «To jest Pan» (J 21,1-19)”, Józef Ratzinger Opera Omnia. XII. Głosiciele Stowa i studzy Waszej radości (red. K. Góźdź - M. Górecka) (Lublin 2012) 469-475.

Schütz Ch., ,Tajemnice życia Jezusa jako pryzmat wiary”, Communio 23/1 (2003) 10-24.

Sikora J., Od Słowa do słowa. Literackość współczesnych kazań (Warszawa 2008).

Simon H., „Przepowiadanie biblijne”, Biblia w nauczaniu chrześcijańskim (red. J. Kudasiewicz) (Lublin 1991) 49-86.

Simon H., Celebrare la salvezza: dottrina e prassi del culto (Torino 1986).

Siwek G., „Ewangelizacyjna funkcja homilii”, Homo Dei 62/4 (1993) 84-97.

Siwek G., „Kaznodzieja jako świadek”, Stuga Słowa (red.

W. Przyczyna) (Redemptoris Missio 13; Kraków 1997) 83108.

Sorentino A., Celebracje liturgiczne. Sztuka przewodniczenia (Kraków 2009).

Staniek E., „Kazanie w starożytności chrześcijańskiej”, Fenomen kazania (red. W. Przyczyna) (Kraków 1994) 15-27.

Szewczyk L., Recepcja liturgicznego wymiaru homilii. Studium homiletyczne na podstawie badań kaznodziejstwa kapłanów archidiecezji katowickiej w latach 1972-1999 (Katowice 2003).

Szram M., „Chrystus - Mądrość Boża jako klucz interpretacyjny Pisma Świętego w ujęciu Orygenesa", Mistrz i przyjaciel. Księga pamiątkowa ku czci księdza profesora Marka Tomasza Zahajkiewicza (red. J. Pałucki) (Lublin 1997) 225-238. 
Świerzawski W., Mysterium Christi. Chrystus obecny w liturgii i życie chrześcijańskie (Kraków 1975).

Turowski W., „Kaznodzieja świadkiem Ewangelii”, Świadectwo w stużbie Ewangelii (red. W. Przygoda) (Lublin 2012) 245-264.

Twardy J., „Kazanie jako akt «mowy żywej»”, Mowa żywa. Wybrane aspekty komunikacji kaznodziejskiej (red. J. Twardy - W. Broński - J. Nowak) (Kielce 2005) 153-163.

Twardy J., ,Medytacja kaznodziejska”, Współczesna Ambona 3 (1993) 130-138.

Witczyk H., „Rola biblistyki w procesie kształcenia kaznodziejów", Integralne kształcenie kaznodziei (red. W. Broński) (Lublin 2006) 141-158.

Zerfass R., Od perykopy do homilii (Kraków 1995).

Żądło A., „Egzystencjalno-pedagogiczny wymiar Eucharystii”, Przeglad Homiletyczny 11 (2007) 123-135.

Ks. Stanistaw Dyk

ul. Radziszewskiego 7

20-039 Lublin

standyk@kul.pl

Ks. StanisŁaw Dyk, kapłan diecezji kieleckiej, profesor nauk teologicznych, kierownik Katedry Homiletyki Katolickiego Uniwersytetu Lubelskiego Jana Pawła II w Lublinie, wiceprzewodniczący Stowarzyszenia Homiletów Polskich, redaktor naczelny „Przeglądu Homiletycznego”, redaktor tematyczny 12 . zeszytu „Roczników Teologicznych KUL” - „Homiletyka”, autor książek oraz kilkudziesięciu artykułów naukowych, wykładowca homiletyki i teologii ewangelizacji. Ostatnie publikacje zwarte: „, Co głosic, aby wierzyli?" Studium homiletyczne Lekcjonarza mszalnego (Lublin 2013), Nowa ewangelizacja konkretne wezwanie (Gubin 2015). 